\title{
INCREASING STUDENTS' MOTIVATION ON LEARNING WRITING SKILLS THROUGH INQUIRY APPROACH
}

\author{
Sitti Hamsina S \\ Institut Parabikma Indonesia (IPI) Gowa \\ hamsina@parahikma.ac.id
}

\begin{abstract}
This present study investigated students' motivation for learning writing skills through an inquiry approach. The research methodology that was used the type of descriptive research using correlational, where the researchers wanted to know the motivation of students as well as see differences in student motivation in learning writing skills through an inquiry approach. This study used purposive sampling and the respondents were the tenth-grade students of MAN 3 Makassar consist of two classes. They are the 10th Science grade that used the inquiry approach and the 10th Social grade with a non-inquiry approach consists of 30 students in each class. Collecting data in this study used a close question by using the MSLQ. Then to analyze the data, the present researcher used a paired samples t-test by using SPSS 22 for windows. Based on the data analysis, the present researcher found that the mean score of and the 10th Science grade for three motivation scales namely: control belief (5.76), self-efficacy (5.68), and anxiety (5.46) and the 10th Social grade got control belief (5.18), self-efficacy (5.14), and anxiety (4.99). The interpretation scale of the three motivation scales of the 10th Science grade obtained a mean score higher than the 10th Social grade. The t-scores of the three scales, two of them of control belief scale and self-efficacy scale were a significant difference at 0.05 level and the anxiety scale was not a significant difference. The present researcher states that the inquiry learning approach could increase students' motivation for learning writing skills for the tenth grade of MAN. Based on the results of this study, researchers currently expect that English teachers could use the inquiry learning approach to teach English writing skills.
\end{abstract}

Keywords: Motivation, writing skills, inquiry approach.

\section{A. INTRODUCTION}

here were three components very important to improve the quality of learning in the educational environment, namely: teachers, students, and the environment.

L According to Putra, A. S., Jie, N. J., \& Kiong, T. K. (2012) successful learning and learning processes were supported by variables sourced from students themselves, teacher efforts in creating learning, and adequate environmental facilities. However, teachers should try to apply the principles of motivation in the teaching and learning process to improve student motivation in learning. In the learning process, there must be necessary that there is motivation from students to support the objectives of the learning process. One opinion of education experts that emphasizes the importance of motivation in learning (Rahman, A. S., Nurjannah, S., \& Utami, I. R.,2018), "Literal motivation is as an impulse that arises in a person directly or unconsciously, to act with a specific purpose in learning.

Learning is a complex activity and involves various interrelated aspects. The teacher's efforts to develop students' potential are a very important part of achieving learning goals. Therefore the selection of models, strategies, approaches, and learning techniques is an 
important thing. Achieving high-quality education is not only determined by students, but also influenced by the teacher and other supporting factors, especially in learning to write English Mattarima, K., \& Hamdan, A. R. (2011. English language learning is inseparable from the four language skills namely, listening, reading, speaking and writing, of the four skills, most students consider writing skills to be the most difficult skills because to master writing skills, students must carefully pay attention to the use of grammar, vocabulary, punctuation, spelling, and content (Rahayu, R., Suyitno, A., \& Sugiharti, E. 2012).

The ability to write to students needs to improve their motivation. As research conducted by Munipah, E. (2008) revealed that writing skills help improve students' skills, for example, think logically, find solutions to solve problems, so they can learn from the problems they face. Besides verbal ability is very influential on the quality of writing made by students, especially the ability to absorb information. According to Ginting, B., \& Chekita, D. (2019), a person didn't have a talent for writing because he didn't know what to write for and feels he didn't know how to write. Dislike could not be separated from the influence of the family environment, community, and learning experience in writing that is less motivated. Wibisono, Y. (2017) stated that the writing learning experience experienced by students in school is inseparable from the approach used by the teacher.

Besides teaching and learning English many approaches could be used to teach students based on the material or potential possessed by students. The students who learned English will succeed if the learning approach is interrelated with what was needed by students in teaching and learning activities. One suitable strategy in teaching writing skills was the inquiry learning approach (Tanto and Luciana, 2009). There were several studies on learning approaches that are an integral part of learning English, especially English writing skills (Pearson, 2007; Colwell, 2003). Crawford et al. (1996) state that when English teachers teach certain texts, not only describe the flow, symbols, and themes related to the text. If this is done according to Crawford et al., Students learn without real understanding. Therefore teachers must use inquiry-based approaches to help students understand life and experiences in real-time through writing. Writing English learning Through an inquiry approach, students can make clear connections between what they are learning and real life.

\section{B. REVIEW OF LITERATURE}

\section{Motivation}

According to Suprihanto et al, (2003) suggested that motivation is a force that drives individual activities to carry out an activity to achieve goals. Meanwhile, Dimyati and 
Mudjiono (1999), stated that motivation as a mental impulse in which there is activating, moving, channeling, and directing human behavior to behave and behave to learn.

Motivation is one of the factors that determine the success of students in learning. Several studies and research on this matter have been carried out. Shams examined student behavior, motivation, and anxiety towards teaching English in Pakistan Shams, Meenaz. (2008). The results of his research published in his article entitled Students' Attitudes, Motivation, and Anxiety towards English Language Learning show that most of the students studied had the motivation that was both instrumental and integrative. Students wanted to learn English because they wanted to master English so they could participate in the development of a global world. Meanwhile, research conducted by Marlina on student motivation in English showed that the motivation that underlies most students who study and master English was getting better jobs because English was an important language in the development of the world economy. The study examined the motivation seen from the course-specific motivation component and teacher-specific motivation component (Marlina, Lenny. 2007).

According to Mendari, A. S., \& Kewal, S. S. (2015) In learning motivation, there were 3 components, namely: (a) control belief component (b) Self-efficacy component refers to the intrinsic value components the drive to do something requires an intrinsic drive, which comes from within the individual. This encouragement was in the form of feeling happy with the lecture material, pleasant classroom atmosphere, and challenging assignments given by the lecturer so that they could improve their abilities; (c) Anxiety component is the anxiety level of an individual. This component is an effective component such as student reaction and emotional in this case in the form of student anxiety over examinations and assignments (Darmawati: 2009).

In learning, motivation is very necessary. If there is motivation, the learning outcomes would be optimal. The better motivation was provided by the teacher and the more successful for the learning. Therefore, motivation always determines the success of the learning effort for students (Sardiman, 2001: 82). The teacher should use a good approach to increase student motivation in learning. The approach in the teaching and learning process are all activities and steps in conducting teaching and learning to support the objectives of the learning process. Herrel and Jordan (2004) state that approaches that can be used in various fields are approaches that support the objectives of the teaching and learning process. Whereas Kindsvatter (1998) states that a good approach used in teaching is those general teachers can provide various fields of science to students in learning activities. 


\section{Inquiry Approach}

The inquiry method is a way of conveying lessons by studying something critical, analytical, and argumentative in nature by using certain steps towards conclusions (Keys, C. W., \& Bryan, L. A., 2001). The inquiry method pays attention to encouraging students to develop problems.

The inquiry approach was a student-centered learning approach. This approach engages students in generating ideas, communicating actively, both in writing, and sharing learning experiences that are expected to provide better meaning (Tanto and Luciana, 2009; Crawford et al. 1996,). Furthermore, to be a successful student, they must learn to build confidence all the time. For sustainable practice with effective experiences, students need a support model before and during inquiry learning (Friedrichson \& Meis, 2006). Teachers need to know in the field of content to be taught with the inquiry approach. But many teachers still do not have an understanding of how to teach with the inquiry approach. (Milatasari, Y.U. (2013).

Furthermore, Brown's study (2008), students made observations and take field notes as a laboratory to enhance their future learning. Students need to have the ability to find their answers and investigations. Students are challenged and encouraged to direct their learning or become independent learners. Furthermore, learning is an investigation, according to Atkinson et al. (2008), which can also improve students' high thinking skills. It can be concluded that students are still struggling to be independent and have high-level thinking skills. Thus, inquiry learning can be a teaching approach to achieve high levels of thinking for students. Meanwhile, Scardamalia (2002), stated that the teacher should use the inquiry approach to be active in the learning process by allowing students the opportunity to build a culture in which ideas are challenged, ask questions, and find out for themselves what is understood, curiosity function as possible. while Kuklthau, Maniotes \& Caspari (2007), states that the inquiry approach provides an opportunity to ask questions and provides more opportunities for those who answer correctly.

An inquiry learning approach was a learning approach that was suitable for the teachers in teaching writing skills (Akhiruddin, A. 2019). In the writing learning process, there are three roles for the teacher to be implemented, namely: the teacher as a motivator, the teacher as a resource (giving facilitation and clarification), and the teacher as a provider of feedback (Harmer, 2002). In this case, the teacher should take full responsibility in the teaching and learning process.

The teaching approach that is the focus of this research is the inquiry learning approach. The study of inquiry-based approaches to learning has been carried out by several experts, 
including the use of inquiry-based approaches in science subjects (Friedrichson \& Meis, 2006; Harada and Yoshina, 2004), as well as inquiry approach can be used in many fields of knowledge (Atkinson et al 2008).

\section{Writing skill}

Writing is a productive and expressive activity namely, skill is a productive activity that could produce something. in this case, the writer could express feelings or their circumstances in writing that can be read or enjoyed by the readers (Alawi, F. F., 2011). While (Al-Jumaily, Samir, 2014) stated that writing is lowering or depicting graphical symbols that describe a language understood by someone so that other people can read the symbols of the graph when they understand the language of the graphic image.

Learning English writing skills for high school students is directed to achieve students' ability to express different meanings. Students are expected to take rhetorical steps in the written text of a topic related to real-life experiences with an emphasis on written language features. Learning writing skills was one of the strong language skills, intended to produce writing (Toukan, K., Alnoaimi, T., \& Odibat, A. 2006). The students abroad showing difficulties in writing skills. Learning writing skills due to uncertainty and difficulty is a problem for individuals especially students who study English as a foreign or second language (Beydoga, 2011; Fathi Huwari \& Noor Hashima, 2011). This difficulty was caused by the low frequency of using foreign languages, especially in writing. Most writing skills learning activities are carried out in daily programs written in their own country.

Furthermore, previous research (Talebinezhad and Negari, 2009; Beydoĝa, 2011; Fathi Huwari \& Noor Hashima, 2011). It could be concluded that the teacher competency needs to be restored in developing students' writing skills especially in teaching and learning English as a foreign language. One of the skills teachers need to develop is the ability to use various teaching approaches and write them into the syllabus of learning syllabi and lesson plans.

Alimashudin (2008) found in one of high school in Makassar, Indonesia that among the four English language skills, writing skills became more difficult than other skills (reading, reading, and speaking). Therefore, learning English writing skills requires knowledge of grammar, vocabulary, spelling, and mechanics, intending to provide students with connections between the knowledge they have and their implementation in family and community life.

English subjects in high schools were stated as one of the goals of learning English was to develop language skills, both in oral and written form. Writing skills were language skills that were thinking activities that create ideas or expressions in written form (Al-Jumaily, Samir, 2014). Communicate orally and in writing using language that was fluent and accurate 
in discourse or interactional monologues. This involves formative discourse, descriptions, narratives, spoofs, recounts, procedures, reports, news items, anecdotes, exposures, explanations, discussions, comments, and reviews with a variety of simple interpersonal, ideational, and textual meanings.

Writing skills are one of the language skills and an activity that was related to thinking and expression skills in writing. Although learning writing skills is one of the four language skills, in the language learning process. It is not possible to separate from other language skills such as listening, speaking, and reading. The four language skills complement each other. As in the 2006 curriculum of students studying English in high school, it was stated that one of the goals of learning English was to develop oral and written language achievement.

There are several elements of writing, including grammar, paragraph organization, and vocabulary. Also, there are mechanics of writing which are necessary for making good writing. We should have a good idea to produce good writing. (Syamsuri, Muhsin \& Nurmayani, 2016). The students would be bored and not interested in writing if they didn't have ideas to write what topic they will write. (Patel \& Jain, 2008); When they have to find the right words to make ideas then when to determine and look for the right words. (Anderson \& Anderson,1997).

The teacher had writing experience, but the students felt worried about English correctly because they didn't dare to do it (Heaton, J. B, 1989). They were worried to express their ideas in writing paragraphs and language research papers (Patel, 2008). Meanwhile, (Byrne, 1986) states that they were worried about their ideas in the use of grammar, punctuation, and spelling correctly, and they didn't have motivation.

\section{METHOD}

This research was included in the type of descriptive research using correlational, where researchers wanted to know the motivation of students in learning the writing skill through the inquiry learning approach. The population in this study were students of the tenth grade of MAN 3 Makassar, amounting to 120 students. The researcher chose the sample from two classes that had similar characteristics. They were the 10th Science grade that used the inquiry approach and the 10th Social grade used a non-inquiry learning approach, consist of 30 students in each class. This study used purposive sampling as a sampling technique.

Collecting data in this study used a close question by using the MSLQ scale developed by Printich and Groot (1990) and consists of 18 items. The MSLQ questionnaire uses a 7-point Likert scale. firstly it was translated into Indonesian using a back-translation technique and 
validated by 3 experts from English teachers. Regarding the validation and reliability process, the MSLQ questionnaire in the Indonesian version was distributed to both classes. Then to analyze the data, The data of this study were collected and analyzed by using descriptive statistics and inferential analysis. Descriptive analysis was used to know the mean and standard deviation of students' scores in the three scales of motivation.

\section{FINDINGS AND DISCUSSION}

The motivation of both classes was measured using the Motivation Strategy Language Questionnaire. The MSLQ questionnaire used a 7-point Likert scale ranging from never true to always true. The interpretation scale $1.00-1.50$ is exceptionally low, $1.51-2.50$ is very low, 2.51-3.50 is low, 3.51-4.50 is medium, $4.51-5.50$ is high, 5.51-6.50 is very high, 6.51-7.00 is exceptionally high. In this case, there were three Motivation scales would be measured namely: control belief scale, self-efficacy scale, anxiety scale. These three scales had18 items; 6 items of control belief items, 4 items of self-efficacy, and 8 items of confidence.

The difference in student motivation between the 10th Science grade and the 10th Social grad, the following would explain the mean and standard deviation of each motivation scale. The table below showed the mean score and the standard deviation of the three motivation scales.

Table 1. The Result of Mean score and Standard Deviation

\begin{tabular}{llccc}
\hline Scale & Grade & N & Mean & SD \\
\hline Control Belief & 10th Social & 20 & 5.18 & 1.09 \\
& 10th Science & 20 & 5.76 & 0.60 \\
& Total & 40 & 5.47 & 0.91 \\
Self-Efficacy & 10th Social & 20 & 5.14 & 0.60 \\
& 10th Science & 20 & 5.68 & 0.49 \\
& Total & 40 & 5.41 & 0.60 \\
Anxiety & 10th Social & 20 & 4.99 & 0.95 \\
& 10th Science & 20 & 5.46 & 0.81 \\
& Total & 40 & 5.22 & 0.90 \\
\hline
\end{tabular}

Analysis of the data in the table showed that there were three motivation scales used in this study, namely: control belief, self-efficacy, and anxiety. the mean score of the control belief scale for the 10th Social grade got the mean score was 5.18 (high) and the 10th Science grade got a mean score of 5.76 (very high). This means that the 10th Science grade had a higher mean score on the control belief scale than the 10th Social grade. While the mean score of the self-efficacy scale for the 10th Social grade got a value of 5.14 (high) and the 10th Science grade got a mean score of 5.68 (very high). This means that the 10th Science grade got a higher value than the 10th Social grade. while the anxiety scale for the 10th Social 
grade got a mean score was 4.99 (high) and the 10th Science grade got a mean score of 5.46 (high). This means that the 10th Science grade produced a higher score than the 10th Social grade. In this case, it was concluded that the motivation of the three scales of the 10th Science grade was a higher score. Meanwhile, the interpretation scale of the 10th Science grade obtained interpretation scale very high, very high, and high and the 10th Social grade got high, high, and very high. Based on the results of the mean score and the interpretation scale of the three motivation scales, it can be concluded that the 10th Science grade that used the inquiry learning approach obtained a mean score higher than the 10th Social grade that used with a non-inquiry learning approach. Based on the data described it was concluded that the inquiry approach was good to be used in learning especially in English writing skills.

The present researcher used a paired sample t-test by using SPSS 22 for windows to calculate the data. The hypothesis in this study was an inquiry approach significantly increase students' motivation in learning writing skill for the tenth grade of MAN. In this case, the three motivation scales and the result can be seen in Table 2 .

Table 2: Difference tests of motivation scales between the 10th Science grade and the 10th Science grade.

\begin{tabular}{|c|c|c|c|c|c|}
\hline Scale & & $\mathrm{F}$ & Sig. & $\mathrm{T}$ & $\begin{array}{l}\text { Sig. (2- } \\
\text { tailed) }\end{array}$ \\
\hline \multirow{3}{*}{ Control of Belief } & Equal variances assumed & 5.737 & .022 & 2.058 & .047 \\
\hline & Equal variances not assumed & & & & .048 \\
\hline & Equal variances assumed & 1.714 & .198 & 3.082 & .004 \\
\hline \multirow[t]{2}{*}{ Self-Efficacy } & Equal variances not assumed & & & & .004 \\
\hline & Equal variances assumed & 3.026 & .090 & 1.676 & .102 \\
\hline Anxiety & Equal variances not assumed & & & & .102 \\
\hline
\end{tabular}

The different test results of learning motivation between the 10th Science grade and the 10th Science grade used the independent sample t-test in table 2 showed that the significance value between the two classes was analyzed respectively 2.058 in control belief scale, 3.082 in self-efficacy scale, and 1.676 in anxiety scale. The t-scores of the three scales, two of them namely, control belief scale and self-efficacy scale were a significant difference at 0.05 level and the anxiety scale was not a significant difference at 0.05 level. It could be concluded that there was a significant difference in control of beliefs and self-efficacy between the 10th Science grade that used the inquiry learning approach and the 10th Social grade with a noninquiry learning approach. On the other hand, the anxiety scale did not show a significant difference between the 10th Science grade and the 10th Social grade. Based on the result of the calculation above, the present researcher states that the inquiry learning approach could increase students' motivation for learning writing skills for the tenth grade of MAN. 


\section{CONCLUSION}

Based on the results of the analysis and discussion described, it could be concluded that:

1. The motivation scale used in this study was the control belief scale, self-efficacy scale, and Anxiety scale. the mean score of the control belief scale for the 10th Social grade got a mean score was 5.18 and the 10th Science grade got a mean score of 5.76. This means that the 10th Science grade had a higher mean score on the control belief scale than the 10th Social grade. While the mean score of the self-efficacy scale for the 10th Social grade got a value of 5.14 and the 10th Science grade got a mean score of 5.68. This means that the 10th Science grade got a higher value than the 10th Social grade. While the Anxiety scale for the 10th Social grade got a mean score was 4.99 and the 10th Science grade got a mean score of 5.46. This means that the 10th Science grade produced a higher score than in the 10th Social grade. The interpretation scale of the 10th Social grade for the control belief scale was very high, the self-efficacy scale was very high, and the anxiety scale was high. Meanwhile, the 10th Social grade obtained interpretation scale of control belief scale was high, the self-efficacy scale was high, and the anxiety scale was high. It was concluded that the motivation of the three scales, the 10th Science grade was a higher score.

2. The t-scores of the three scales of the significance value between the two classes were analyzed respectively 2.058 in the control belief scale, 3,082 in self-efficacy scale, and 1,676 in the anxiety scale. The different test results of the motivation scales of control belief scale and self-efficacy scale were a significant difference at the 0.05 level and the anxiety scale was not a significant difference at the 0.05 level. It could be concluded that there was a significant difference in control belief scale and self-efficacy scale between the 10th Social grade and the 10th Science grade. Meanwhile, the anxiety scale did not show a significant difference between the 10th Science grade that used the inquiry learning approach and the 10th Social grade with a non-inquiry learning approach.

\section{REFERENCES}

Akhiruddin, A. (2019). Peningkatan Hasil Belajar Sosiologi Pada Pokok Bahasan Nilai Dan Norma Melalui Pembelajaran Inquiry Siswa Kelas X Sma Negeri 16 Makassar. Socioedu Journal (Pendidikan, Sosial, Humaniora), 3(2).

Alimahsudin. (2008). Improving the Paragraph Writing Ability of the Eleventh year Students of SMA Negeri 1 Namelea Through Process Strategy. Makassar: State University of Makassar. 
Sitti Hamsina S, Increasing Students' Motivation...

Al-Jumaily, Samir. (2014). Improving my students' writing skills: an intensive course for ESL learners by using process-approach to writing with the assistance of the computer word processor. 2(1),29-35.

Anderson, M., \& Anderson, K. (1997). Text types in English (Vol. 2). Macmillan Education AU.The effectiveness of inquiry-based learning in teaching writing ability for the eighth graders of SMPN 2 Selong in the school year 2014-2015 [Undergraduate thesis]. Hamzanwadi University, NTB, Indonesia.

Atkinson, Maxine P. Hunt, \& Andrea N. (2008). Inquiry-Guided Learning in Sociology. Teaching Sociology; 36, 1: 1-7.

Beydoga, H. Ömer. (2011). Effects of Mind Map Supported Cognitive Preparation on Expository Writing. Abi Evran Üniversitesi Kırşehir Eğitim Fakültesi Dergisi KEFAD, 12, 4: $1-23$.

Brown, J. (2008). Student-Centered Instruction: Involving Students in Their Own Education. Music Educators Journal: 94, 30-35.

Byrne, D. (1986). Teaching oral English (Vol. 2). Harlow, UK: Longman.

Colwell, A. (2003). An Explanation of Inquiry in the English Classroom. http://www.ed.psu/englishpds/inquiry/projects/colwell.pdf.

Crawford, Kathleen \& Short, Kathy. (1996). Learning Together Through Inquiry. Portland, Maine: Stenhouse Publishers.

Darmawati, Arum. (2009). Analisis Motivasi Dan Pengaturan Diri Untuk Belajar Mahasiswa Jurusan Manajemen Fakultas Ilmu Sosial Dan Ekonomi Universitas Negeri Yogyakarta.Tidak Dipublikasikan.

Fathi Huwari, Ibrahim \& Noor Hashima Abd Aziz (2011). Writing Apprehension in English Among Jordanian Postgraduate Students At Universiti Utara Malaysia. Academic Research International, 1.2.

Friedrichsen, P. \& Meis. (2006). Brokering at the Boundary: A Prospective Science Teacher Engages Students in Inquiry. Science Education, v90, 522- 543.

Harada, V. H., \& Yoshina, J. M. (2004a). Moving from rote to inquiry: Creating learning that counts. Library Media Connection, 23, 22-24.

Harmer, J. (2001). The practice of English language teaching. Longman.

Heaton, J. B. (1989). Writing English Language test. London and New York: Longman Group.

Herrel, Adrienne L, and Michael L. Jordan. (2012). Fifty strategies for teaching English language learners, 4th edition. Pearson: US

Kindsvatter, R., Willia, W., \& Margaret, I. (1998). Dynamics of effective teaching. White Plains. NY: Longman. 
Kuhlthau, Carol C., Leslie K. Maniotes., Ann K. Caspari. (2007). Guided inquiry (learning in the $\left.21^{s t}\right)$

Marlina, Lenny. (2007). Motivation and Language Learning: A Case of EFL Students. Jurnal KOLITA. Unika Atma Jaya.

Mendari, A. S., \& Kewal, S. S. (2015). Motivasi Belajar Pada Mahasiswa. Jurnal Pendidikan Akuntansi Indonesia, 13(2)

Milatasari, Y.U. (2013). Improving students' ability in writing through inquiry-based learning. Universitas Sebelas Maret. Retrieved from http://jurnal.fkip.uns.ac.id/index.php/bhs inggris/article/view/7878 on October 12 $\underline{2017}$.

Patel, M. F., \& Jain, P. M. (2008). English language teaching. Sunrise Publishers and Distributors.

Pearson, E.F. (2007). Assessing Writing Through Reflection: A Qualitative Inquiry. Ph. D Dissertation. Lowa State University.

Putra, A. S., Jie, N. J., \& Kiong, T. K. (2012). Enhancing student involvement in a class using a real-time response system. In 2012 International Conference on Information Technology Based Higher Education and Training (ITHET) (pp. 1-4). IEEE.

Sardiman, A.M. (2001). Interaksi dan Motivasi Belajar Mengajar. PT. Rajagrafindo Persada, Jakarta.

Scardamalia, M. (2002). Collective cognitive responsibility for the advancement of knowledge. In CBS (special edition \#32). Retrieved from http//cbs/2017 on September 272017

Shams, Meenaz. (2008). Students' Attitudes, Motivation and Anxiety towards English Language Learning. Journal of Research and Reflections in Education. Vol. 2, No.2, pp 121 144 http://www.ue.edu.pk/jrre

Syamsuri, A. S., Muhsin, M. A., \& Nurmayani, N. (2016). The effectiveness of caricature media in learning writing of argumentation paragraph. Theory and Practice in Language Studies, 6(11), 2079-2086.

Talebinezhad, M. R. and, Negari, G. M. (2009). The Effect of Explicit Teaching of Concept Mapping in Expository Writing on EFL Students' Self-regulation. Paحhuhesh-e Zabanhaye Khareji, 49, Special Issue: 85-108.

Tanto Setia Mulyanto, Luciana Syahman (2009). Pengembangan Kompetensi Bahasa Inggris Di SMA Dengan Menggunakan Pendekatan Inkuiri Melalui Kegiatan "Independent Movie Festival: Anti Bullying Campaign”. Jurnal Penelitian, 9, 1.

Toukan, K., Alnoaimi, T., \& Odibat, A. (2006). National Education Strategy. Amman: Ministry of Education, Directorate of Education. 